\title{
FREEDOM OF MARRIAGE FOR WOMEN WHO SHE WANT, CLASHES BETWEEN CULTURE AND HUMAN RIGHT LAW. LOMBOK, WEST NUSA TENGGARA. INDONESIA
}

\author{
Lalu Hendri Nuriskandar \\ Master Student of Law Faculty, The National University of Malaysia \\ Email: laluhendrinuriskandar.ukm@gmail.com \\ Shahrul Mizan bin Ismail \\ Lecture of Law Faculty, The National University of Malaysia \\ Email: shahrulmizan@ukm.edu.my
}

\begin{abstract}
Women are human beings created who are born with human rights. This right is inherent without distinction between men and women. One of the inherent rights is to love and marry. However, it will be a problem if these rights are limited by tradition and parents. That is what happened in Bonjeruk Village, Jonggat District, Central Lombok Regency, West Nusa Tenggara, Indonesia. Women who want to get married must be in accordance with the wishes of their parents, namely at least have a knighthood. Even if their daughters love people who do not have a royal title, they will never be allowed to marry. As a result, many girls are adults but not yet married. Thus, this article aims to find out how Human Rights Law views this matter. By using a descriptive qualitative approach, the writer will try to answer and solve these problems. To support this, the authors use literature review as material to collect data. If it is linked to human rights law, it is a violation of the rights to have children, have a spouse and freedom to choose a life partner. In addition, what is the main barrier is culture, meaning that it is the culture that prevails in the village, and must be obeyed. However, for women it is torture.
\end{abstract}

Keywords: Marriage; Human Rights; Women.

\section{A. INTRODUCTION}

One of the most important transitions in human life is the transition from adolescence to adulthood and family life, namely by way of marriage. In language, marriage means joining and gathering. While according to Islamic Sharia, marriage is a strong agreement between a man and a woman. ${ }^{1}$ When compared to other transitional periods, marriage is the phase that gets the most attention. ${ }^{2}$ Apart from being a human nature, marriage has also become a necessity for Islam, because marriage will result in offspring. Thus, it will be one of the ways to practice Maqashid Shari'ah, namely maintaining descendants (Hifdzun Nashab). Apart from religion, marriage is also heavily intervened by customs and culture. As what happened in many countries around the world, including Indonesia.

One of the inherent rights of humans is the right to marry, where one of the purposes of this marriage is to keep the offspring from being cut off there. Marriage is a human nature and instinct. Marriage is considered as a phase of life that almost certainly occurs in every human being. Javanese people call it kinanthi. Therefore, people, each ethnicity and country have different ways of carrying out this marriage. The thing that plays the most role is related to custom, which can even be against religion or even can conflict with human rights itself, especially for women.

${ }^{1}$ E. Mustafa, AF. Islam Builds Families and Marriage Law in Indonesia, (Yogyakarta: Kota Kembang, 1987) Page. 21

${ }^{2}$ Kontrajiningrat,Principles Someof Social Anthropology, (Jakarta: Dian Rakyat, 1997). Page 4 


\section{[JATISWARA] [Vol. 36 No. 1 Maret 2021]}

One of them is on the island of Lombok, which has different procedures in the marriage process, starting from the initial selection of a partner, the marriage process and other events such as walimahan. In contrast to the general tradition of starting a marriage carried out by the Muslim community, namely by means of a sermon or by proposing. The Muslim Sasak community generally uses the tradition (Merarik) kawin lari. This means that the man takes the woman away from his house, and it is usually done at night after evening prayers and before Isha. In the process of this marriage, sometimes there are conflicts between the woman who does not want to marry the man, but because it has been taken, she will inevitably be married off to the man. However, this case is very rare. Habit they both like.

Something different, happened in Bonjeruk Village, girls were not given the freedom to choose the companion they wanted. This is contrary to the rights inherent in a man and woman.

A study conducted by Iklilah Muzayyanah concluded that, even though women have plans for their lives, the position of women with power relations is not equal to men, making them vulnerable to various manipulations and putting women in a situation of being unable to refuse, unable to avoid, and unable to maintain her own authority in the decision to marry the person she loves. Marriages that occur to women do not always reflect the basic ideas of Islamic culture and religion that pay respect to women's humanity and recognition of women's existence. $^{3}$

Iklilah added that in the conception of marriage culture in Lombok, women are given autonomy in determining their choice of life partner. In this context, culture places women as subjects who have authority over their bodies, however, the fact is that some women in their twenties have undergone two to three marriages, even fourth or more marriages. ${ }^{4}$ In contrast to what happened in Bonjeruk, women who are even over 30 years old are not allowed to marry, because they are limited by the customs and culture of their ancestors. Bonjeruk women are not free to decide whom to marry. The man must have at least a peerage. Apart from that, the man also had to pay dowry and money Pisuke a largeto get married. Of course this is the customary law and also the women's family.

The phenomenon that occurs can be concluded that, some of these marriage practices have violated women's rights to marry. Women are not free to choose the husband they love. In addition, the socially inferior position of women is strengthened by the subordination of women's interests in decision making. As a result, the purpose of the cultural concept that has long been built in the Sasak moslem community has lost its meaning.

The marriage of noble women in the context of gender places them in a position that is not free, according to Harfin Zuhdi, the gender bias in the stratification of noble Sasak women causes them to have limited access and powerlessness in determining their mate. This causes many Sasak aristocratic women to marry late and even do not get married due to strict and rigid customary rules and regulations. However, if she is determined to marry a man with a lower strata, then she will receive the consequences of customary sanctions, namely being expelled from the family and placing her in a marginal and subordinative position. ${ }^{5}$ This condition has placed Sasak aristocratic women in an unfavorable position, thus giving birth to various forms of injustice against women. Judging from human rights, a woman with a title or no title has the right to decide who she wants to marry. A woman has the right to express and get love from the man she wants to marry. However, the practices that occur are not as contained in theory.

${ }^{3}$ Iklilah Muzayyanah dini Fajriyah, Sasak Muslim Women in the Practice of Interesting Marriage Culture: A Anthropological Study of Religious Perspectives of Women:Journal: Al-Fikr Volume 16 Number 3 of 2012. Page. 95

${ }^{4}$ Ibid, P. 87

${ }^{5}$ Muhammad Harfin Zuhdi, 2013, Merarik Tradition: Acculturation of Isam and Local Culture. Leppim: IAIN Mataram. Page 35

12 Lalu Hendri \& Shahrul Mizan | Freedom of Marriage... 


\section{B. ANALYSIS AND DISCUSSION}

\section{Marriage Practice in Bonjeruk (Lombok)physical and}

Marriage is a spiritual bond between a man and a woman to form a happy and lasting family based on divinity. Birth bond is a formal relationship that can be seen because it is formed according to law, which binds both parties and other parties in society. Meanwhile, an inner bond is an informal relationship which is formed with a mutual willingness that truly binds both parties. The marriage bond is a sacred bond based on divine values to form a Sakinah, mawaddah, and merciful family. ${ }^{6}$

In Indonesian, marriage means forming a family with the opposite sex. Having sex or intercourse. ${ }^{7}$ Marriage according to religious law is a sacred act, namely a bond between two parties in fulfilling the commands and advice of God Almighty, so that family and household life and kinship run well in accordance with their respective religious teachings. So, this marriage can be said to be a physical and spiritual bond that has legal consequences on the religion of the prospective bride and the family of her relatives. ${ }^{8}$ According to an anthropological perspective, marriage is a relationship between an adult man and woman who mutually establish customary law or religious ties with the intention that they maintain this relationship for a relatively long time. ${ }^{9}$

Every human being certainly wants to live life with the people he loves without coercion from anyone, including family. However, not everything that is desired goes smoothly. Especially noblewomen in bonjeruk, they are not entitled or limited in their rights to marry the man they love. This is not because of religious differences, but because of the difference in caste between aristocrats and non-aristocrats, and the pisuke money that the female family asks for the male party is so large that it cannot be fulfilled. Thus, the marriage will not occur. This is a problem for women, as if they are restricted and do not have the right to love. In fact, when referring to religious teachings, there is nothing to prevent them from getting married, except for differences in faith.

The main thing that prevents a bonjeruk woman from marrying the man she loves is because of the title. Royal women must marry a man who has a noble title. An example of a title for girls is "Lale" which comes before the name. Meanwhile, men have the title "Lalu" or "Raden" which is at the beginning of their name as well. Meanwhile, men who do not have this title may not marry a noble woman. Apart from that, ethnic differences are also the cause of the prohibition of the marriage of aristocratic women in Bonjeruk Village. However, it would be different if a noble male was to marry. They were freed to marry women who did not have royal titles. Men are also given the right to marry the woman they like without having to look at their ethnicity and also their royal status. This is a very striking difference between men and women. When viewed from the perspective of human rights law, women and men have the same right to love without being restricted. However, because the customs and culture adopted have deprived women of these rights.

In the book Alif lam Mim written by John Ryan Bartholomew, it is revealed that the phenomenon that often occurs in the marriage of aristocratic women is when a noble woman marries a non-aristocratic man who is not compatible. Sebaai wanted to distance inheritance and exile because he had married an ordinary person, as had been regulated by their village custom.

${ }^{6}$ Muhammad Yusuf Al-Hamdani, The Wedding Tradition of Nobles from a Gender Perspective (Phenomenological Studies in the Village of Pengembur). Thesis, UIN Maulana Malik Ibrahim Malang: 2016. Page. 16

${ }^{7}$ M. Idrus Ramuliyo.(2004). Islamic Marriage Law, Jakarta: PT Bumi Aksara. Page 7

${ }^{8}$ Hilman Hadikusuma.(1990). Marriage Law in Indonesia According to Religion, Bandung: Mandar Maju. Page 10

${ }^{9}$ Ariyono Suyono.(1985). Dictionary of Anthropology, Jakarta: Akademika Pressindo. Page 315 
However, most families on the woman's side put down the fact that at least she had to lose her royal status as a punishment. This practice of exile, many Muslims express condemnation of this practice on the basis that there is no single Islamic law that justifies it. ${ }^{10}$

According to Budiwanti, ${ }^{11}$ in the tradition of marriage between noble women and nonaristocratic men, they will receive various fines, making the costs to be borne by the groom very large. This condition is not only burdensome for the groom, but also puts the woman in a dilemma. These rules make women not free to choose their life partner, because they have to wait for someone who can afford the sajikrame. ${ }^{12}$

From the explanation above, it can be concluded that cases that often occur will disturb the socio-psychological conditions of noble women. On the other hand, it describes an attitude of inferiority, namely the powerlessness of women for all the actions they experience. This condition causes a number of Sasak women in Bonjeruk Village, especially those with aristocratic titles, to not marry. This condition is very far from the principles of justice and human rights, it is also incompatible with gender justice.

When talking about gender, gender is often understood and interpreted in terms of discrimination or differences that are considered to bring harm and suffering to women. This means that gender has significantly positioned women to be unequal and subordinate to men. The emergence of this gender problem is motivated by a cultural situation where the functions and roles of women are limited by a system of certain values and norms so that this limitation is considered to be the hiding of women's rights. ${ }^{13}$ The marriage pattern of aristocrats is usually endogamous, meaning that it will not be possible to have marriages from people with different caste backgrounds. As a result of the above social status, if it is against it, it will become a clash or conflict. ${ }^{14}$ That is what causes clashes and even conflicts. Therefore, the division of status and roles is culturally considered a problem where the aristocratic status of women will lead to discrimination.

\section{Impact of Marriage Practice in Bonjeruk A}

A noblewoman who wants to marry a non-aristocratic man will certainly get rejection from parents, family and also customs. Because, they are not considered as partners to carry out the marriage. However, if you are already in love, nothing can separate the two loves that want to unite through marriage. The method that will be used is by taking the girl from her house without the knowledge of her parents and this is called pulling. In the Indonesian context, ideally a marriage must pass through the stage of preaching or proposing. However, in the tradition of marriage in the Sasak community, there are four (4) ways, namely: 1. Married by means of making a splash (Forced kidnapping), 2. Giving up the law, (the marriage is handed over to the woman). 3, melakoq (applying to the woman's parents), and the fourth. Marriage tadong (Hanging Marriage). However, in its development, not all forms of marriage are still practiced. One way that is still practiced in the tradition of the people of Lombok is "merarik", which is the joint agreement between a man and a woman to marry and plan to run away from the house at night which has been agreed to hide in the man's family house. And this method is the most and suitable to be done if they are not approved when asking nicely from the woman. ${ }^{15}$

\footnotetext{
${ }^{10}$ John Ryan Bartholomew.(2001). Alif Lam Mim: Local Wisdom of Sasak Society, Yogyakarta : Tiara Discourse. Page. 250

${ }^{11}$ Budiwanti in Muhammad Yusuf Al-Hamdani, The Wedding Tradition of Noble Gender Perspectives (Phenomenological Studies in the Village of Pengembur). Thesis, UIN Maulana Malik Ibrahim Malang: 2016. Page.7

${ }^{12}$ Sajikrame is a fine imposed on the groom who has a lower social status than the bride

${ }^{13}$ Mansour Fakih.(2013). Gender Analysis and Social Transformation. Yogyakarta: Pustaka Pelajar. Page 9.

${ }^{14}$ Elly M. Setiadi \& Usman Kolip, 2011, Their Solutions Introduction to Sociology, Understanding the Facts and Symptoms of Social Problems: Theory, Applications and. Jakarta: Kencana Prenada Group. Page.423

${ }^{15}$ Iklilah Muzayyanah Dini Fajriyah, Muslim Women.... Page. 86
} 
The Sasak people, especially in Bonjeruk Village, are widely known to acknowledge their social stratification, and this has become the norm that regulates social relations among the Sasak people. ${ }^{16}$ Research conducted by Muslihun found that social strata are still valid in Sasak society in general. The triwangsa stratification divides humans into three levels, namely Datu (aristocrats), Pemenak-Pewangsa and Jajar Karang. The Datu group is the highest class, the pemenak-pewangsa is the middle class. Meanwhile, jajar karang is the lowest group in the Sasak ethnic strata. Jajar karang consisted of people and slaves called sepangan. ${ }^{17}$ The sociological reality above has greatly influenced the tradition of marriage, especially the Sasak Muslim community on the island of Lombok who are very strong in defending their nobility, one of which is the village of Bonjeruk, Central Lombok. Matchmaking was the thing most defended among aristocrats because they wanted to maintain their status and privileges. The desire to emulate the socially authoritative practices of the nobility may also influence matchmaking practices. $^{18}$

According to the triwangsa principle, families with lower strata are not allowed to marry women from families with higher levels and so on. However, not the other way around, a highstratified family may marry a woman with a lower strata and this marriage does not result in a lower level of rank, unless the one he marries is a married woman, panjak pirak or a slave. So automatically his ranking will go up, even down because he has done a wrong procedure which is called sanyak (dirty). ${ }^{19}$

The influence of this caste title is evident in the process of selecting a partner. Therefore, women's marriages are limited only within the scope of the same caste. Caste rules are very decisive in the process of determining a life partner. Even though in principle, sasak marriage is based on mutual liking. However, the reality is that noble women do not have the freedom to make choices or decide who to marry.

In line with this phenomenon, it is very clear that in the process of choosing a mate, women's rights are very limited in choosing a life partner. In addition, it can be seen that there is a huge dominance of parents, in this case the father, to marry off his daughter to whom he wants without having to ask the girl's consideration.

If the marriage is between an aristocratic girl and a non-noble man, the following will happen:

\section{Not Given a Guardian}

A woman who forces her to marry a man of her heart even though she is not a noble, so from the family, especially the father, will not approve of their relationship. The disagreeable form was not to give them guardians. The woman's parents will not want to be the guardian of her child marriage. So that in practice, many are married using a guardian judge. This happens because the woman has been in the man's house for a long time and there is a fear of slander.

\section{Being Banished from A Noble Family}

Not only does it end there, but the woman will also no longer be recognized as a child by the family. Even though his name is still listed on the family card, the parents will not want to know about the condition of their child. This means that they have released their child.

\footnotetext{
${ }^{16}$ Baharudin.(2007). Nahdlatul Wathan and Social Change, 2nd Press. Yogyakaarta: Genta Press. Page. 64

${ }^{17}$ Muslihun, Shifting the meaning of pisuke / gantiran in the Culture of Merarik Sasak Lombok, Leppim Journal: IAIN Mataram. 2009. Page. 44.

${ }^{18}$ John Ryan Barthholomew.(2001). Alif Lam Mim ... Page.164

${ }^{19}$ Muslihun, Opcit, Page. 45
} 


\section{Not Receiving Inheritance from Family The}

Their Suffering experienced by women who do not follow their parents is compounded by not receiving inheritance from their parents. Whereas if it refers to the teachings of Islam, women have the right to inherit $1 / 2$ of men's share.

\section{Their descendants do not get the title of nobility.}

The inherited system is from the male side, so even though the female has a noble title and the male does not have a title. So their offspring will not get the title of descent.

\section{The Tradition of Royal Marriage in Bonjeruk Village}

The wedding ceremony is a cycle of celebrating the marriage process that is passed when there is a marriage between a noble man and a noble woman in Bonjeruk Village. This tradition is also a common tradition practiced by the indigenous people of the Sasak tribe. As for the implementation of traditional marriage after the implementation of the marriage, all the series of processes must be carried out because it contains values that will later affect the status of the bride and groom, especially for aristocratic women. ${ }^{20}$

\section{a. Mesejati This}

means that from the male side sent several local community leaders or traditional leaders to report to the village head or hamlet head to announce the marriage's identity about the prospective groom's identity and then report to the woman's family.

According to M. Nur Yasin, mesejati in Sasak language means telling the truth about something. Mesejati comes from the true word which in Sasak language means truth. Marriage means notification from the male family to the girl's family that the girl in question has really been stolen by the man in the hope that the woman's family will not be confused about finding her child. ${ }^{21}$

b. Selabar

Selabar contains the meaning of announcing to the woman's family which is followed up by a discussion of customs including Aji Krame. ${ }^{22}$

\section{c. $\quad$ Ngendeng Wali (Picking up Wali)}

Ngendeng Wali is a request to the parents of the prospective bride and groom to be willing to be guardians in their child's marriage. This custom is usually carried out several hours before the implementation of the marriage contract..$^{23}$

\section{d. Taking Promises}

In the implementation of this promise taking is to discuss the sorong serah and aji krame according to the customs that apply in the village or village of origin of the prospective bride. ${ }^{24}$

\section{e. Ngawinan (Marriage)}

Ngawinan in Sasak language means the process of implementing the Kabul marriage contract or consent in accordance with religious provisions.

\footnotetext{
${ }^{20}$ Sudirman.(2007). Gumi Sasak Sejarah, dalam Mataram: Yayasan Buddaya Sasak Lestari . Page. 82-83

${ }^{21}$ M. Nur Yasin.(2008). Past Marriage Law of Sasak, Malang: UIN Press. Page. 226

${ }^{22}$ Sudirman, Gumi Sasak in History. Page. 82

${ }^{23}$ John Ryan Bartholomew.(2001). Alif Lam Mim: Local Wisdom of the Sasak Society, Page.192

${ }^{24}$ Sudirman, Gumi Sasak Sejarah, page 82
} 


\section{f. $\quad$ Sorong Serah (Aji Krame)}

Sorong serah comes from the word "sorong" which means to encourage, and "serah" which means to give up. So the sorong handover is a statement of agreement between the two parties, both male and female, in the marriage procession of the two brides. The essence of the implementation of the sorong serah is the official announcement of the marriage ceremony of a man and a woman and there is no longer allowed to talk about matters related to customs. ${ }^{25}$ In addition, the sorong serah also aims to reconcile the two sides of the family who may be fighting from all the processes that have been passed, namely from the beginning of the woman being taken to the last event (sorong serah). ${ }^{26}$

\section{g. Nyongkolan}

Usually, a few days after the submarine event, the groom's family accompanied by the bride and groom come to visit the female family accompanied by relatives and friends who are usually accompanied by traditional musical instruments typical of the Sasak tribe. This Nyongkolan is done apart from being an event to spread to the general public that there has been a marriage between the two parties and as a gathering place between the two extended families of the two brides. [27]

\section{h. Balik Lampak or Gathering}

Nulakang lampak nae is the last event in the wedding ceremony. The bride and groom together with the parents of the man will pay a special visit to the house of the woman's parents. This event aims to connect the relationship and introduce family members to each other, both from the family members of the groom and from the family of the woman. So that when they meet on the street they can get to know each other and greet each other. ${ }^{27}$

\section{The Right of Women in Indonesian Laws}

Article 27 paragraph 1 of the 1945 Constitution, which explains the recognition of the principle of equality for all citizens without exception. This principle of equality eliminates discrimination, therefore every citizen has the same rights before the law and the government regardless of religion, ethnicity, position, class and gender. Moempoeni Martojo, said that; "The term citizen, of course, implies both a woman and a man". ${ }^{28}$ What Moempoeni said was true, because anywhere in the world, of course, the citizens consist of men and women. The recognition of equal rights for citizens means that there are no differences between men and women. The recognition of the principle of equality before the law and the government in the Constitution shows that the founders of the State of Indonesia, before establishing the state, were very aware of the importance of protecting human rights. ${ }^{29}$

Juridically, at the national and international levels, Indonesian legal instruments and regulations recognize the principle of equal rights between men and women, however, at the level of implementing state administration, discrimination, and injustice against women. Women are always left behind and marginalized in the fields of economy, education, health, work, in politics and also in love (marriage). Because some areas in Indonesia, it is very burdensome to the marriage process for women related to costs and customs. Among them are the Bugis

\footnotetext{
${ }^{25} \mathrm{Ibid}$, Page 82

${ }^{26}$ M. Nur Yasin, Sasak Islamic Marriage Law, Page. 277

${ }^{27}$ Sudirman, Gumi sasak in History, Page. 82

${ }^{28} \mathrm{Ibid}$, Page 82

${ }^{29}$ Moempoeni Martojo.(1999).Face of Principles of Equality in theLaw for Women and Its Implementation in Indonesia. Dissertation. Semarang: Universitas Diponegoro. Page. 2
} 
Makassar tribe, the Minang tribe in Padang, and including the Sasak Aristocratic tribe in Lombok. One of the reasons is the patriarchal culture that develops in Indonesia's indigenous peoples. In a society with a patriarchal culture, men are more involved in holding power, which can automatically degrade the role and existence of women. ${ }^{30}$ By following the principle of equal rights in all fields, both men and women have the same rights or opportunities to participate in every aspect of public and state life and including in determining their marriage. So, if there is discrimination against women, it is a form of violation of women's human rights.

The struggles of women in achieving equality and justice that have been carried out for a long time have not been able to raise the dignity of women to be equal with men. Even though the highest power in Indonesia has been held by women, namely President Megawati Soekarno Putri, and many women have held strategic positions in government, gender injustice and the backwardness of women have not been resolved as expected. What is also rarely seen is related to the very basic thing for women, namely marriage. In some of the cases mentioned above, customary law with State law and Islamic law are in conflict, which is burdensome for women. Women are still marginalized and left behind in all aspects of life, including in the field of law. This is a formidable challenge for women and the government. Among the laws and regulations that contain the content of protecting women's human rights are: Law Number 39 of 1999 concerning Human Rights, Law Number 23 of 2004 concerning the Elimination of Domestic Violence, Law Number 12 of 2006 concerning citizenship, Law Number 21 Year 2007 concerning the eradication of the criminal act of trafficking in persons, and Political Law (Law No.2 of 2008 and Law Number 42 of 2008). Then Presidential Instruction No. 9 of 2000 on Gender Mainstreaming (PUG) and Presidential Decree No. 181 of 1998 concerning the Establishment of the National Commission on Violence against Women or Women National Commission as amended by Presidential Decree Number 65 of 2005.

\section{a. Law Number 39 of 1999 concerning Human Rights}

After being independent for 44 years, Indonesia only had a human rights law in 1999. In contrast to America, Britain and France which had a bill of rights since the beginning of their independence and made a bill of. their rights as an inseparable part of the constitution. Initially, the Indonesian Constitution did very little in regulating human rights.

This law defines human rights as "a set of rights inherent in the nature and existence of humans as creatures of God Almighty and is a gift that must be respected, upheld and protected by the state, law, government, and everyone for the sake of honor and protection of human dignity"(Article 1 paragraph 1). With the existence of a human rights law, all laws and regulations must be in line with the principles of protecting human rights as regulated in this law. Among other things, the elimination of discrimination based on religion, ethnicity, race, ethnicity, group, class, social status, economic status, gender, language and political beliefs. The prohibition of discrimination is regulated in article 3 paragraph 3, which reads "everyone has the right to protection of human rights and basic human freedoms without discrimination".

Article 1 paragraph 3 and article 3 paragraph 3 explain that discrimination based on sex is prohibited by law. Other legal rules must eliminate discrimination in every aspect of life, social, political, economic, cultural and legal. The articles in this Human Rights Law are always addressed to everyone, this means that all matters regulated in this Human Rights Law are always directed at each person, this means that all matters regulated in the Human Rights Law it is intended for all people of all denominations and genders. ${ }^{31}$

\footnotetext{
${ }^{30}$ Nalom Kurniawan, Women's Rights in Legal and Religious Perspectives, Journal of the Constitution, Vol. IV, No.1. June 2011. Page. 172 179

${ }^{31}$ Dede Kania, Women's Rights in Law in Indonesia, Faculty of Sharia and UIN Law Sunan Gunung Djati Bandung. Page.
} 
However, the problem is, there is no statutory regulation that discusses women's freedom to marry the person she wants without being restricted by customs and culture. Most practice in the field is, a marriage that is not approved by the family will end up in court and make the judge's guardian as a substitute for the female guardian. With the consequence the woman will be thrown out of the family. This applies to aristocratic women. At the level of practice in ordinary society, customary and cultural laws take precedence over state law in the context of marriage.

\section{b. Law Number 12 of 2006 concerning Citizenship}

Law number 12 of 2006 concerning citizenship replaces law number 62 of 1958 concerning citizenship. Philosophically, juridically, and sociologically, Law number 62 of 1958 is considered no longer in line with the development of society and the state administration of the Republic of Indonesia. Philosophically, this Law still contains provisions that are not in line with the philosophy of Pancasila, among others, because it is discriminatory, does not guarantee the fulfillment of human rights and equality of citizenship, and does not provide protection for women and children.

Juridically, the constitutional basis for the formation of the law is the Constitution of 1950 which has not been in force since the decree of the President of July 5, 1959 which states Return to the Constitution of 1945. In its development, the Constitution of 1945 has undergone further changes ensuring protection of human rights and the rights of citizens. Sociologically, the Law is no longer in line with the development and demands of Indonesian society as part of the International community in global association, which requires equality of treatment and position of citizens before the law and equality and gender justice. ${ }^{32}$

Among the specific principles that form the basis of the application of the Citizenship Law is the non-discriminatory basis, which is in the form of non-discrimination in all matters relating to citizens on the basis of race, race, religion, class and gender. The other principle is the principle of recognition and respect for human rights in all matters relating to citizens must guarantee, protect, and glorify human rights in general and the rights of citizens in particular. ${ }^{33}$

An arrangement that eliminates discrimination based on gender among them is to allow a wife who marries a different citizenship, to choose Indonesian citizenship or transfer citizenship following her husband's citizenship. Although the law of the husband's country of origin requires the wife's citizenship to follow the husband's citizenship as a result of the marriage. [34] The rules in the previous citizenship law resulted in a wife losing Indonesian citizenship when she married a foreign man, because she had to follow her husband's citizenship. [35]

A common problem in society is that law-abiding practices are rarely practiced. The lowest case in the community alone cannot be touched by the law. Because it is the authority of customs and parents. In addition, in general, the Indonesian people also do not want to be governed by problems that lead to domestic affairs. As when the government wants to enact sexual violence laws against women. The government wants to regulate that the husband should not be arbitrary in treating his wife, especially in sexual relations. Many people's reactions are rejected, especially by women. For some reason, the government should not interfere in the affairs of the couple in bed. In fact, if viewed in terms of law and provisions, which is benefited even from women. However, due to numerous rejections, the draft law was invalidated.

However, what about the legal provision that women are free to marry the man they want without distinction of race and ethnicity, of course many will agree, especially women who have the title of aristocracy and must marry fellow aristocrats. But, on the other hand, many

\footnotetext{
${ }^{32}$ Explanation of Law Number 12 of 2006 General Section.

${ }^{33}$ Dede Kania, Opcit
} 
will reject, especially from local customs. Because the right to embrace culture and customs is also included in human rights. The dilemma is that, when a force is forced to be applied, it has also indirectly deprived the human rights of others. Then, how to regulate properly, so that all parties benefit. The author of this feeling needs to be studied by the government, so that there is no injustice and no fulfillment of human rights at the lowest level.

\section{Human Right Perspective of Woman Marriage Practice In Bonjeruk}

Since the founding of the United Nations, equality between men and women has been among the most fundamental guarantees of human rights. Adopted in 1945, the Charter of the United Nations sets out as one of its goals "to reaffirm faith in fundamental human rights, in the dignity and worth of the human person, [and] in the equal rights of men and women". Furthermore, Article 1 of the Charter stipulates that one of the purposes of the United Nations is to promote respect for human rights and fundamental freedoms "without distinction as to race, sex, language or religion". This prohibition of discrimination based on sex is repeated in its Articles 13 (mandate of the General Assembly) and 55 (promotion of universal human rights).

In 1948, the Universal Declaration of Human Rights was adopted. It, too, proclaimed the equal entitlements of women and men to the rights contained in it, "without distinction of any kind, such as ... sex, ...." In drafting the Declaration, there was considerable discussion about the use of the term "all men" rather than a gender-neutral term. ${ }^{34}$ The Declaration was eventually adopted using the terms "all human beings" and "everyone" in order to leave no doubt that the Universal Declaration was intended for everyone, men and women alike.

After the adoption of the Universal Declaration, the Commission on Human Rights began drafting two human rights treaties, the International Covenant on Civil and Political Rights and the International Covenant on Economic, Social and Cultural Rights. Together with the Universal Declaration, these make up the International Bill of Human Rights. The provisions of the two Covenants, as well as other human rights treaties, are legally binding on the States that ratify or accede to them. States that ratify these treaties periodically report to bodies of experts, which issue recommendations on the steps required to meet the obligations laid out in the treaties. These treaty-monitoring bodies also provide authoritative interpretations of the treaties and, if States have agreed, they also consider individual complaints of alleged violations. ${ }^{35}$

Both Covenants use the same wording to prohibit discrimination based on, inter alia, sex (art. 2), as well as to ensure the equal right of men and women to the enjoyment of all rights contained in them (art. 3). The International Covenant on Civil and Political Rights guarantees, among other rights, the right to life, freedom from torture, freedom from slavery, the right to liberty and security of the person, rights relating to due process in criminal and legal proceedings, equality before the law, freedom of movement, freedom of thought, conscience and religion, freedom of association, rights relating to family life and children, rights relating to citizenship and political participation, and minority groups' rights to their culture, religion and language. The International Covenant on Economic, Social and Cultural Rights guarantees, for instance, the right to work, the right to form trade unions, rights relating to marriage, maternity and child protection, the right to an adequate standard of living, the right to health, the right to education, and rights relating to culture and science.

\footnotetext{
${ }^{34}$ Johannes Morsink, "Women's rights in the Universal Declaration”, Human Rights Quarterly, vol. 13, No. 2 (May 1991).

${ }^{35}$ For more information on the human rights treaty system, see OHCHR, Fact Sheet No. 30: The United Nations Human Rights Treaty System and OHCHR, Fact Sheet No. 7: Individual Complaint Procedures under the United Nations Human Rights Treaties.
}

20 Lalu Hendri \& Shahrul Mizan | Freedom of Marriage... 
In 1967, United Nations Member States adopted the Declaration on the Elimination of Discrimination against Women, which states that discrimination against women is an offence against human dignity and calls on States to "abolish existing laws, customs, regulations and practices which are discriminatory against women, and to establish adequate legal protection for equal rights of men and women". Less than a year later a proposal for a legally binding treaty on women's rights was made. The Convention on the Elimination of All Forms of Discrimination against Women was adopted by the General Assembly in 1979. Its preamble explains that, despite the existence of other instruments, women still do not enjoy equal rights with men.

The Convention articulates the nature and meaning of sex-based discrimination and lays out State obligations to eliminate discrimination and achieve substantive equality. As with all human rights treaties, only States incur obligations through ratification. However, the Convention articulates State obligations to address not only discriminatory laws, but also practices and customs, and discrimination against women by private actors.

With these general principles as an overarching framework, the specific obligations of States to eliminate discrimination against women in political, social, economic and cultural fields are laid out in 16 substantive articles. The Convention covers both civil and political rights (rights to vote, to participate in public life, to acquire, change or retain one's nationality, equality before the law and freedom of movement) and economic, social and cultural rights (rights to education, work, health and financial credit). The Convention also pays specific attention to particular phenomena such as trafficking, to certain groups of women, for instance rural women, and to specific matters where there are special risks to women's full enjoyment of their human rights, for example marriage and the family.

The Convention defines discrimination in its article 1 as "... any distinction, exclusion or restriction made on the basis of sex which has the effect or purpose of impairing or nullifying the recognition, enjoyment or exercise by women, irrespective of their marital status, on a basis of equality of men and women, of human rights and fundamental freedoms in the political, economic, social, cultural, civil or any other field."

Such discrimination encompasses any difference in treatment on the grounds of sex which:

1. Intentionally or unintentionally disadvantages women.

2. Prevents society from recognizing women's rights in both the private and the public spheres.

3. Prevents women from exercising the human rights and fundamental freedoms to which they are entitled.

The Convention also specifies the different ways in which State parties are to eliminate discrimination, such as through appropriate legislation prohibiting discrimination, ensuring the legal protection of women's rights, refraining from discriminatory actions, protecting women against discrimination by any person, organization or enterprise, and modifying or abolishing discriminatory legislation, regulations and penal provisions. The Convention foresees that achieving equality may require positive action on the part of the State to improve the status of women. To accelerate women's actual equality in all spheres of life, States are permitted to use temporary special measures for as long as inequalities continue to exist. The Convention thus reaches beyond the narrow concept of formal equality and aims for equality of opportunity and equality of outcome. Temporary special measures are both lawful and necessary to achieve these goals. In principle, these measures should be removed once equal status has been achieved.

Importantly, the Convention adds new, substantive provisions to the other instruments which also deal with equality and non-discrimination. Article 5 establishes that in addition to recognizing women's legal equality and promoting their de facto equality, States should also 
strive to eliminate the social, cultural and traditional patterns that perpetuate harmful gender stereotypes and to create an overall framework in society that promotes the realization of women's full rights.

The Convention on the Rights of the Child (art. 2) and the Convention on the Protection of the Rights of All Migrant Workers and Members of Their Families (art. 7) also prohibit discrimination based on sex. The Convention on the Rights of Persons with Disabilities (art. 6) recognizes the multiple discrimination that women with disabilities are subjected to and requires State parties to address this by taking "all appropriate measures to ensure the full development, advancement and empowerment of women" in the enjoyment of their human rights. In its general recommendation No. 25 (2000) on gender-related dimensions of racial discrimination, the Committee on the Elimination of Racial Discrimination, which oversees compliance with the International Convention on the Elimination of All Forms of Racial Discrimination, also recognized the gender dimensions of racial discrimination and said it would "endeavor in its work to take into account gender factors or issues which may be interlinked with racial discrimination." The Committee against Torture, which monitors the Convention against Torture and Other Cruel, Inhuman or Degrading Treatment or Punishment, also regularly addresses issues of violence against women and girls.

\section{CONCLUSION}

Women are born human beings who have human rights that cannot be distinguished from men. In the most fundamental case it should not be hindered or taken away. One of them is the freedom or right to marry the man she loves without being hindered by custom and customs. Referring to Indonesian law and international human rights, a woman's marriage in a Bonjeruk violates a woman's rights, women are too restrained to be able to choose the man she likes to marry.

\section{Preferences}

Ariyono Suyono, 1985, Dictionary of Anthropology, Jakarta: Akademika Pressindo

Article 26 paragraphs 1 and 3. Citizenship Law.

Baharudin, 2007, Nahdlatul Wathan and Social Change, 2nd Press. Yogyakaarta: Genta Press.

Budiwanti in Muhammad Yusuf Al-Hamdani, The Wedding Tradition of Noble Gender Perspectives (Phenomenological Studies in the Village of Pengembur). Thesis, UIN Maulana Malik Ibrahim Malang: 2016

Dede Kania, Women's Rights in Law in Indonesia, Faculty of Sharia and UIN Law Sunan Gunung Djati Bandung

E. Mustafa, AF. Islam Builds Families and Marriage Law in Indonesia, (Yogyakarta: Kota Kembang, 1987)

Elly M. Setiadi \& Usman Kolip, 2011, Their Solutions Introduction to Sociology, Understanding the Facts and Symptoms of Social Problems: Theory, Applications and. Jakarta: Kencana Prenada Group.

Hilman Hadikusuma, 1990, Marriage Law in Indonesia According to Religion, Bandung: Mandar Maju.

Iklilah Muzayyanah dini Fajriyah, Sasak Muslim Women in the Practice of Interesting Marriage Culture: A Anthropological Study of Religious Perspectives of Women:Journal: Al-

22 Lalu Hendri \& Shahrul Mizan | Freedom of Marriage... 
Fikr Volume 16 Number 3 of 2012

John Ryan Bartholomew, 2001, Alif Lam Mim: Local Wisdom of Sasak Society, Yogyakarta :

Tiara Discourse

John Ryan Bartholomew, 2001, Alif Lam Mim: Local Wisdom of the Sasak Society

Kontrajiningrat,Principles Someof Social Anthropology, (Jakarta: Dian Rakyat, 1997).

Law No. 62 of 1958 on citizenship before the amendment.

M. Idrus Ramuliyo, 2004, Islamic Marriage Law, Jakarta: PT Bumi Aksara

M. Nur Yasin, 2008, Past Marriage Law of Sasak, Malang: UIN Press

Mansour Fakih, 2013, Gender Analysis and Social Transformation. Yogyakarta: Pustaka Pelajar.

Moempoeni Martojo, 1999,Face of Principles of Equality in theLaw for Women and Its Implementation in Indonesia. Dissertation. Semarang: Universitas DIponegoro

Muhammad Harfin Zuhdi, 2013, Merarik Tradition: Acculturation of Isam and Local Culture. Leppim: IAIN Mataram

Muhammad Yusuf Al-Hamdani, The Wedding Tradition of Nobles from a Gender Perspective (Phenomenological Studies in the Village of Pengembur). Thesis, UIN Maulana Malik Ibrahim Malang: 2016.

Muslihun, Shifting the meaning of pisuke / gantiran in the Culture of Merarik Sasak Lombok, Leppim Journal: IAIN Mataram. 2009

Nalom Kurniawan, Women's Rights in Legal and Religious Perspectives, Journal of the Constitution, Vol. IV, No.1. June 2011.

Sudirman, 2007, Gumi SasakSejarah, dalamMataram: Yayasan Buddaya Sasak Lestari . 